\title{
Морфологические особенности гамартомы легких: два наблюдения больных кардиохирургического стационара
}

\author{
Захарова В. П., Руденко Е. В., Дорофеева С.И. \\ ГУ «Национальный институт сердечно-сосудистой хирургии имени Н. М. Амосова НАМН» (Киев)
}

\begin{abstract}
В статье представлен опыт двух наблюдений гамартом легких, удаленных у больных, оперированных по поводу кардиохирургической патологии и новообразования легкого. Цель исследования - изучить морфологические особенности гамартом легких. Исследование опухолей выполняли путем макроскопического описания операционного материала и микроскопического анализа гистологических препаратов, окрашенных гематоксилином и эозином, по Ван Гизону, фукселином по Вейгерту, суданом III-IV и методом MSB. Определены морфологические особенности исследуемых опухолей, позволившие идентифицировать новообразования как гамартомы, преобладающим компонентом структуры которых являлась хрящевая ткань. Кроме того, в них присутствовали элементы жировой и фиброзной ткани, а также бронхиальный эпителий. В одном наблюдении опухоль удалили с прилежащей легочной тканью, изменения которой были оценены как результат сдавления легкого опухолью.
\end{abstract}

Ключевые слова: гамартома легких, морфологические особенности, кардиохирургическая патология.

Гамартома легких (ГЛ) - дизонтогенетическое доброкачественное новообразование, которое может содержать элементы бронхов и легочной паренхимы в виде компонентов хрящевой, жировой, фиброзной ткани, а также гладкомышечных клеток и эпителия бронхиального типа. Преимущественной локализацией ГЛ является правое легкое $[3,4,10,11]$. Частота распространенности этой опухоли составляет 60-64\% всех периферических доброкачественных новообразований данной локализации [3]. Гамартомы легких бывают бессимптомными, они обычно являются случайной находкой при рутинном медицинском обследовании [7]. Однако больные, как правило, попадают к пульмонологам из-за наличия неспецифических респираторных симптомов [5].

Гамартома легких может быть как изолированной патологией, так и составляющей «триады Карни», которая характеризуется синхронным или метасинхронным сочетанием лейомиобластомы желудка с гормонально активной экстраренальной параганглиомой и хондромой легкого [2].

Макроскопически опухоли выглядят как солидные или солидно-кистозные образования диаметром до 4 см бело-серого цвета с красно-желтыми прожилками [1]. Известны случаи наличия в легких множественных структур со спорадической кальцификацией («попкорн»-кальцификация), которая четко визуализируется при компьютерной томографии легких [5, 8].

По микроскопическому строению различают несколько вариантов ГЛ в зависимости от преобладания в них компонентов той или иной ткани. Наиболее распространенной является хондроидная гамартома (хондро- ма), которая содержит в основном элементы хряща разной степени зрелости и в меньшем количестве - структуры других тканей, описанных выше [3, 5, 9, 11]. Кроме того, в литературе представлены более редкие варианты ГЛ: лейомиоматозный, липоматозный и фибролейомиоматозный [3, 8]. Наличие разных морфологических вариантов ЛГ часто затрудняет дооперационную морфологическую верификацию вида опухоли [11].

Морфологическую характеристику ГЛ может дополнить цитологическое исследование аспирата опухоли, которое позволяет определить следующие компоненты опухоли: аморфное межуточное вещество, клетки хряща, жировую клетчатку, фибробласты, а также кластеры эпителиальных клеток с умеренным количеством цитоплазмы и круглыми, центрально расположенными ядрами, и гранулярным хроматином [6]. Хотя результаты цитологического анализа не являются достаточно информативными для установления окончательного диагноза гамартомы, но они могут служить основанием для предположения о доброкачественном характере процесса так же, как и данные об отсутствии атипии и фигур митоза. Поэтому патогистологическое исследование ГЛ остается приоритетным в диагностике ГЛ.

Цель работы - определить морфологические особенности гамартомы легких на примере двух наблюдений пациентов, оперированных по поводу кардиохирургической патологии.

Материалы и методы. Морфологическое исследование двух новообразований легких было выполнено в патологоанатомическом отделении ДУ НИССХ имени Н. М. Амосова. Полученный материал резециро- 


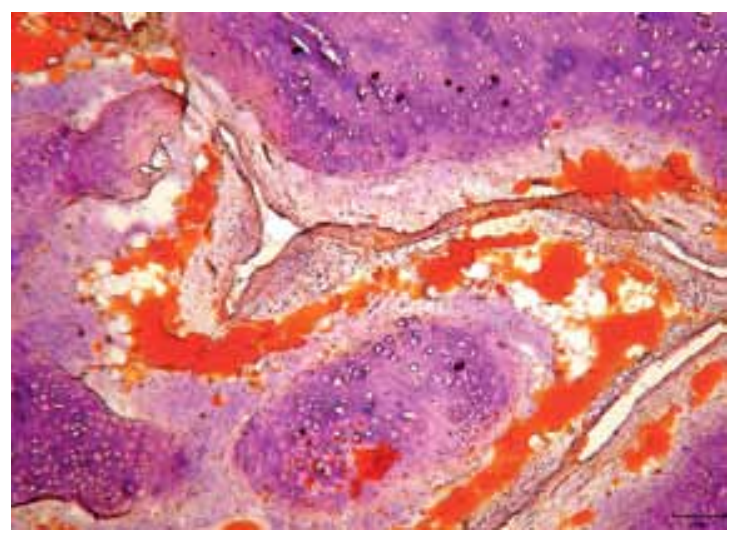

Рис. 1. Б-й Б. Гамартома легких. Чередование участков хрящевой ткани с прослойками жировой клетчатки. Окр. судан III-IV.Ув. х200

ванных опухолей после фиксации образцов подвергали макро- и микроскопическому исследованию. Предварительный диагноз формулировали после исследования замороженных и окрашенных гематоксилином и эозином срезов для проведения обзорной микроскопии и суданом III-IV для выявления липидсодержащих структур. В дальнейшем парафиновые срезы, изготовленные по общепринятой методике, окрашивали гематоксилином и эозином, пикрофуксином по Ван Гизону - для дифференцировки коллагеновых и мышечных волокон, фукселином по Вейгерту - для селективного выявления эластических мембран, MSB для оценки компонентов крови. Микроскопию проводили с помощью системы анализа видеоизображений с микроскопом Olympus BX41 по программе DP Soft.

Результаты и их обсуждение. Сочетание гамартомы легких с кардиохирургической патологией наблюдается редко. В доступной нам литературе найдено лишь одно описание гигантской гамартомы легких у больного с аномальным общим венозным легочным стволом [7]. Однако современная практика выполнения симультанных операций в кардиохирургических клиниках способствует более частому выявлению данной опухоли легких у больных с заболеваниями сердца. В НИССХ НАМН были два таких наблюдения, в которых пациенты поступали в клинику для выполнения кардиохирургических операций после диагностирования гамартомы легких в других медицинских учреждениях.

В первом наблюдении мужчине 56 лет в клинике была выполнена операция аортокоронарного шунтирования (АКШ-2). Во втором случае мужчина 28 лет поступил в НИССХ по поводу аневризмы восходящей аорты для выполнения операции Бенталла. Обе операции сопровождались секторальной резекцией правого легкого для элиминирования ГЛ.

В обоих наблюдениях новообразования имели вид узлов округлой формы с почти одинаковыми диаме-

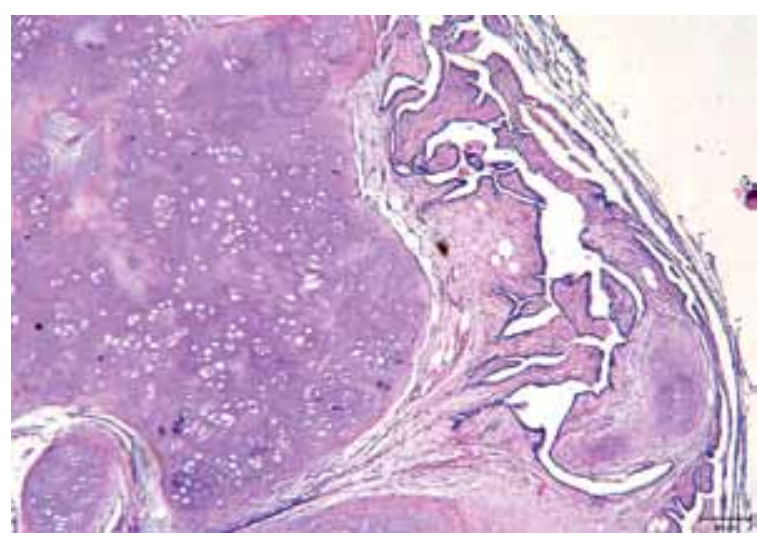

Pис. 2. Б-й Х. Гамартома легких. Трабекулярные структуры, выстланные бронхиальным эпителием. Участки мезенхимной ткани. Окр. гематоксилином и эозином, ув. х100

трами $-1,5-1,6$ см. Опухолевая ткань была хрящевой консистенции, белесого цвета с желтоватыми прожилками. На разрезе дифференцировали псевдокапсулу, определяющую четкие границы опухоли. В первом случае новообразование было удалено вместе с прилежащей тканью, которая макроскопически отличалась от нормальной легочной ткани темно-красным цветом и более плотной консистенцией.

При микроскопическом исследовании препаратов в обоих наблюдениях преобладали элементы зрелого хряща. Однако в первом новообразовании участки хрящевой ткани чередовались с прослойками жировой клетчатки (рис.1), тогда как во втором случае липидсодержащих структур было очень мало, а удаленная вместе с опухолью легочная паренхима была коллабирована, с деформированными, утолщенными альвеолярными перегородками.

В просветах некоторых альвеол содержались десквамированные альвеолоциты, в других - отечная жидкость или малоизмененные эритроциты. Описанные выше признаки изменений легкого, скорее всего, явились результатом длительного сдавления легкого тканью опухоли. Тут же обращало на себя внимание присутствие толстостенных деформированных артерий с гофрированными эластическими мембранами, кое-где были видны сосудистые плексусы, наличие которых могло свидетельствовать о функционировании данного участка легкого в условиях гипертензии. Особенностью второго новообразования было наличие мезенхимоподобной ткани. Кроме того, тут же между элементами хряща встречали хаотично расположенные разновеликие трабекулярные структуры, выстланные эпителием бронхиального типа, местами с признаками дистрофии (рис. 2).

В препаратах обоих новообразований митозы не обнаружены. 


\section{Выводы}

1. Представленные новообразования демонстрируют типичное для ГЛ морфологическое строение, описанное в специальной литературе, что позволяет отнести их к гамартомам легких, причем с типичной локализацией в правом легком в обоих случаях.

2. Отсутствие фигур митоза позволяет отнести эти опухоли к доброкачественным новообразованиям.

3. Основным компонентом новообразований является хрящевая ткань, что свидетельствует о преобладании в данных опухолях хрящевой дифференцировки.

\section{Литература}

1. Синельников А. Я. Атлас макроскопической патологии человека: учебное пособие / А. Я. Синельников. М. : РИА. Новая волна, изд. Умеренков, 2007. - 320 с.

2. Триада Карни: сложности диагностики / И. Ю. Ватанская, Т. И. Степаненко, С. В. Ярцева [и др.] // Science Rise. - 2015. - № 4/4 (9). - C. 54-61.

3. Гамартома легких: предмет исследования и опыт наблюдения / Н. В. Васильев, Е. Н. Самцов, П. Г. Байдала // Сибирский онкологический журнал. - 2008. № 3 (27). - C. 77-81.

4. Surgical treatment and outcome of pulmonary hamartoma: a retrospective study of 20-year experience / Wei Guo, Yun-Ping Zhao, Yao Guang // Journal of Experimental \& Clinical Cancer Research. - 2008. - № 27. - P. 8.
5. Multiple pulmonary chondroid hamartoma / Mingui Fan, Yingying Lin, Lunxu Liu // Journal of thoracic oncology. 2014. - Vol. 9. - № 7. - P. 1053-1054.

6. Pulmonary hamartoma: cytological study of a case and literature review / T. Umashankar, Acharya K. Devadas, G. Ravichandra [et al.] // Journal of Cytology. - 2012. Vol. 29, № 4. - P. 261-263.

7. Successful removal of a giant pulmonary hamartoma coexisting with an anomalous common pulmonary venous trunk / Hui Shi, Zhong-Xi Niu, Jun Peng [et al.] // Journal of Thoracic Disease. - 2015. - № 7 (3). - E23-E27.

8. A rare pulmonary hamartoma: fibroleiomyomatous hamartoma/ Yoshinobu Ichiki, Junji Kawasaki, Takayuki Hamatsu [et al.] // Springer Open / Surgical Case Reports. - 2016. - P. 2:53.

9. Incendental detection of pulmonary hamartoma by echocardiography / I. Dongel, B. Turan, M. M. Can, M. Bayram // Arch. Turk. Soc. Cardiol. - 2011. - P. 628-629.

10. Pulmonary chondroma: A clinicopathological study of 29 cases and review of literature / Dong Tian, Hongying Wen, Yu Zhou, Maoyong Fu // Mol. Clin. Oncol. - 2016. - № 5 (3). - P. 211-215.

11. Пикунов М. Ю. Множественные хондроматозные гамартомы легких / М. Ю. Пикунов // Хирургия. 2004. - № 9. - C. 66-67.

12. Multiple chondromatous hamartomas of the lung//Interactive cardiovascular and thoracic surgery / A. Bini, M. Grazia, F. Petrella, M. Chittolini // Interactive CardioVascular and Thoracic Surgery. - 2002. - Vol. 1, № 2. - P. 78-80.

\title{
Morphological peculiarities of pulmonary hamartoma: two cases of cardiosurgical patients
}

\author{
Zakharova V. P., Rudenko O. V., Dorofeeva S. I.
}

National M. M. Amosov Institute of Cardiovascular Surgery National Academy of Medical Sciences of Ukraine (Kyiv)

The article presents two observations of pulmonary hamartoma in patients, which were operated on the cardiosurgical pathology and neoplasm of the lung. Purpose of the work: to study the morphological features of the pulmonary hamartoma. The tumors study was performed by macroscopic description of the surgical material and microscopic analysis of histological preparations stained with hematoxylin and eosin, by van Gison, fukselin by Weigert, Sudan III-IV and MSB method. The morphological features of these tumors have been determined, that allowed to identify neoplasms as hamartomas, the predominant component of which structure was cartilage tissue. In addition, they contained elements of fat and fibrous tissue, as well as bronchial epithelium. In one case the tumor was removed with adjacent pulmonary tissue and its changes were evaluated as a result of compression of the lung by pulmonary hamartoma.

Key words: pulmonary hamartoma, morphological features, cardiosurgical pathology.

\section{Морфологічні особливості гамартоми легень: два спостереження пацієнтів кардіохірургічного стаціонару}

\author{
Захарова В. П., Руденко О. В., Дорофєєва С. І.
}

\author{
ДУ «Національний інститут серцево-судинної хірургії імені М. М. Амосова НАМН» (Київ)
}

У статті представлено досвід двох спостережень гамартом легень, видалених у хворих, оперованих з приводу кардіохірургічної патології та новоутворення легені. Мета дослідження - вивчити морфологічні особливості гамартом легень. Дослідження пухлин виконували шляхом макроскопічного описання операційного матеріалу та мікроскопічного аналізу гістологічних препаратів, забарвлених гематоксиліном і еозином, за Ван Гізоном, фукселіном за Вейгертом, суданом III-IV і методом MSB. Визначено морфологічні особливості досліджуваних пухлин, що дозволили ідентифікувати новоутворення як гамартоми, домінуючим компонентом структури яких була хрящова тканина. Крім того, в них були наявні елементи жирової та фіброзної тканини, а також бронхіальний епітелій. В одному спостереженні пухлину видалили з прилеглою легеневою тканиною, зміни якої були оцінені як результат стискання легені пухлиною.

Ключові слова: гамартома легких, морфологічні особливості, кардіохірургічна патологія. 